\title{
Estimating Mechanical Behavior of Scaffolds with Graded Porosity by Finite Element Analysis
}

\author{
Meltem Eryildiz ${ }^{1 *}$ \\ 1* Beykent University, Faculty of Engineering-Architecture, Department of Mechanical Engineering, İstanbul, Turkey, (ORCID: 0000-0002-2683-560X), \\ meltemeryildiz@beykent.edu.tr
}

(1st International Conference on Applied Engineering and Natural Sciences ICAENS 2021, November 1-3, 2021)

(DOI: 10.31590/ejosat.1008251)

ATIF/REFERENCE: Eryildiz, M. (2021). Estimating Mechanical Behavior of Scaffolds with Graded Porosity by Finite Element Analysis. European Journal of Science and Technology, (28), 511-514.

\begin{abstract}
3D printing, which is commonly known as additive manufacturing, was around for decades. It allowed users to create 3D objects using computer software and computer aided design (CAD). Due to the increasing use of 3D printing for engineering, the development of tools and strategies to improve the mechanical behavior of printed parts has become necessary. Scaffolds with gradient porosity becomes an attractive candidate for bone tissue engineering. In this paper, a novel hybrid scaffold with a graded pore structure similar to the bimodal structure of cortical and cancellous bones was described. The scaffolds were designed as hybrid, they had three and two grade as 200-300-500 $\mu \mathrm{m}$, and 200-500 $\mu \mathrm{m}$. Porosity of the scaffolds was calculated. Stress analysis of the hybrid scaffolds with graded porosity was carried out to simulate mechanical behavior. According to FEA results, porosity had negative effect on the mechanical properties of the scaffolds. Due to its lower porosity $200-500 \mu \mathrm{m}-\mathrm{b}$ hybrid scaffold had highest mechanical properties according to FEA analysis.
\end{abstract}

Keywords: Finite Element Analysis, PLA, FDM, Stress Analysis, Mechanical Behaviour

\section{Kademeli Gözenekli Doku İskelelerin Mekanik Davranışının Sonlu Eleman Analizi ile Tahmin Edilmesi}

$\ddot{O} \mathbf{z}$

Eklemeli imalat olarak bilinen 3D baskı, uzun zamandır kullanılmaktadır. Eklemeli imalat bilgisayar yazılımı ve bilgisayar destekli tasarım (CAD) kullanarak 3B nesneler oluşturmasına izin vermektedir. 3D baskının mühendislik için artan kullanımı nedeniyle, basılı parçaların mekanik davranışını iyileştirmek için araç ve stratejilerin geliştirilmesi gerekli hale geldi. Kademeli gözenekli doku iskeleleri, kemik doku mühendisliği için oldukça önemlidir. Bu çalışmada, kortikal ve süngerimsi kemiklerin bimodal yapısına benzer kademeli gözenek yapısına sahip yeni bir hibrit doku iskele geliştirilmiştir. Doku iskelesi hibrit olarak tasarlanmış olup, 200-300-500 $\mu$ m ve 200$500 \mu \mathrm{m}$ olmak üzere üç ve iki kademeli gözenekte tasarlanmıştır. Doku iskelelerin gözenekliliği hesaplanmıştır. Mekanik davranışı simüle etmek için kademeli gözenekli hibrit doku iskelelerin stres analizi yapılmıştır. FEA sonuçlarına göre gözenekliliğin doku iskelelerin mekanik özellikleri üzerinde olumsuz etkiye sebep olduğu görülmüştür. Daha düşük gözenekliliği nedeniyle $200-500 \mu$ m-b hibrit doku iskelesi, FEA analizine göre en yüksek mekanik özelliklere sahip olmuştur.

Anahtar Kelimeler: Sonlu Elemanlar Analizi, PLA, FDM, Gerlime Analizi, Mekanik Özellik.

\footnotetext{
* Corresponding Author: meltemeryildiz@beykent.edu.tr
} 


\section{Introduction}

Additive manufacturing (AM), otherwise known as threedimensional (3D) printing, is a process where parts are generated layer by layer. Additive manufacturing technology, also known as 3D printing, had been around for decades and it has allowed users to fabricate custom $3 \mathrm{D}$ objects using computer software and computer aided design (CAD) [1-2].

Fused deposition modeling (FDM) is one of the widely used AM technique for fabricating three dimensional (3D) complex components by depositing the material layer by layer through a very fine liquefier nozzle that moves in $\mathrm{X}$ and $\mathrm{Y}$ direction (in the plane of build platform). After depositing one layer, the build platform (or the worktable) is lowered in Z direction and the next layer is added. In FDM technique, the model and support materials are deposited through a separate liquefier nozzles mounted on the extrusion head [3].

3D printers often generate parts that are modeled as solid objects in CAD software, but when fabricated, the shapes include user specific infill geometries, which replace the solid internal volume with a more material efficient, structural lattice known as infill. These infill geometries are generated by proprietary or open source slicing algorithms and are utilized to generate the numerical code or g-code necessary to manufacture using consumer-grade 3D printers, but unless deliberately accounted for in the CAD model, transform the geometry and thereby invalidates simulation results [4].

Usually a scaffold design uses of regular lattice structures with periodically repeating unit cells [5]. Scaffolds are porous structures that act as a substrate and enable the cells to adhere and grow by means of porous surface. Porous scaffold structures require some characteristics such as; proper porosity that enable the cells to attach to pore network and grow through the pores, necessary mechanical properties that mimic the tissue or nondefected natural bone, biocompatible with living tissue and eliminating or minimizing tissue rejection, a proper surface roughness to promote cell adhesion and spreading. By changing the type of unit cell, different mechanical properties can be obtained because of the coefficient of unit cells. Obtaining different unit cells allows for freedom in the design of porous scaffold that meets appropriate mass transport properties and pore size and in this way, the required mechanical properties can be achieved. Therefore, the scaffolds with different unit cell or hybrid structures which match and mimic strengths, stiffness, porosity and mechanical behavior, allows for avoiding stress shielding and stimulating bone regeneration. In this regard, researches about improving the properties of the scaffold by designing it as hybrid structure are continuing. Additionally, larger pores may be needed for the generation of the bone marrow through the center of the scaffold, while smaller pores may be needed away from the center of the scaffold for the transfer of the nutrition among the alive cells. All these investigations show that structurally hybrid designed scaffolds are promising for tissue engineering applications [6].

In this paper, we describe a novel hybrid scaffold with a graded pore structure similar to the bimodal structure of cortical and cancellous bones. Finite element (FE) analysis is carried for the scaffolds to simulate mechanical behavior. The goal of this study is to provide designers with an essential set of design guidelines based on experimentally obtained data and insights that they can rely on when designing hybrid scaffold.

\section{Material and Method}

The CAD images of the scaffolds and the coding of them are given in Figure 1. The scaffolds were designed as hybrid and they had three and two grade as 200-300-500 $\mu \mathrm{m}$ and 200-500 $\mu \mathrm{m}$. In the experimental study, the scaffold was designed as $10 \times 10 \times 4$ $\mathrm{mm}$. The CAD data of the scaffolds were all changed in STL format and then translated into G-code sliced with slic3r (Figure 2). Slic3r is an open source slicer software. Porosity of the scaffolds was calculated using CATIA V5 program.

Porosity of the built scaffolds was calculated by weighing the scaffolds by using CATIA V5 program and calculating their mass using Eq.1

$$
\text { Porosity }(\%)=\frac{W_{\text {solid }}-W_{\text {scaffold }}}{W_{\text {solid }}} \times 100
$$

Where Wmain was the measured solid scaffold, Wscaffold was the measured weight of the scaffold.

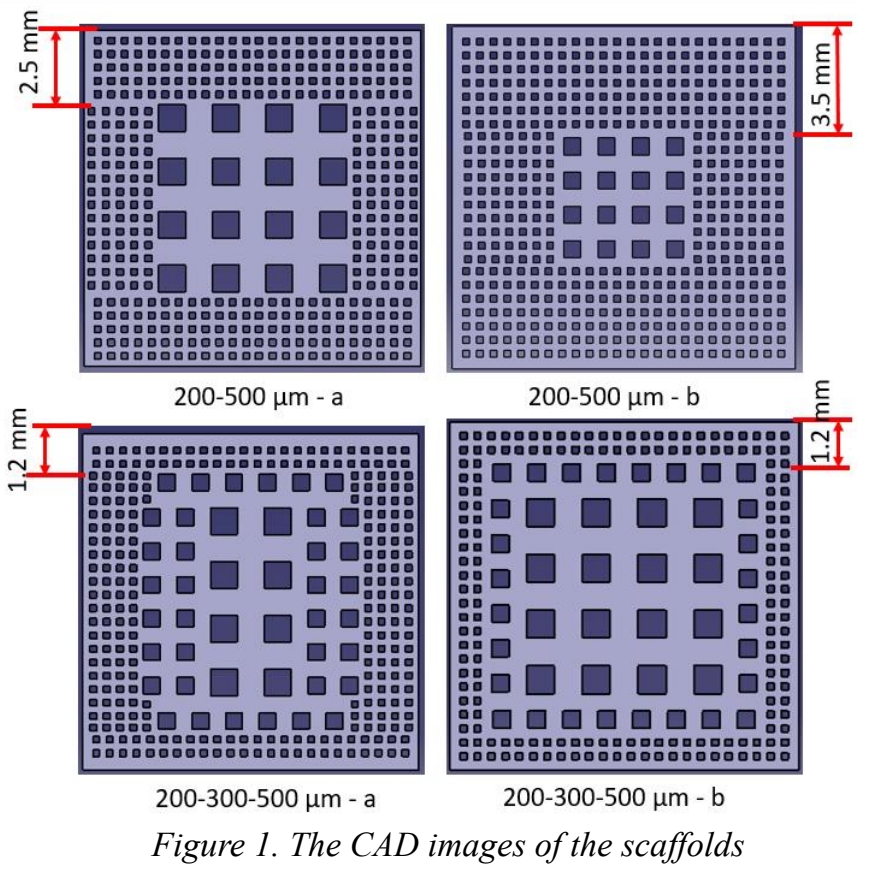

Static analysis was done on the hybrid scaffolds with graded porosity by employing $100 \mathrm{~N}$ load. The material data used in CATIA V5 analysis was PLA (polylactic acid) with specifications as shown in Table 1.

Table 1. Material properties of PLA in CATIA V5 for static analysis

\begin{tabular}{cc}
\hline Properties & Value \\
\hline Young Modulus & $3.2 \times 10^{9} \mathrm{~N} / \mathrm{m}^{2}$ \\
Poisson Ratio & 0.331 \\
Density & $1240 \mathrm{~kg} / \mathrm{m}^{3}$ \\
Thermal Expansion & $6.84 \times 10^{-5}{ }^{\circ} \mathrm{K}$ \\
Yield Strength & $6 \times 10^{7} \mathrm{~N} / \mathrm{m}^{2}$ \\
\hline
\end{tabular}



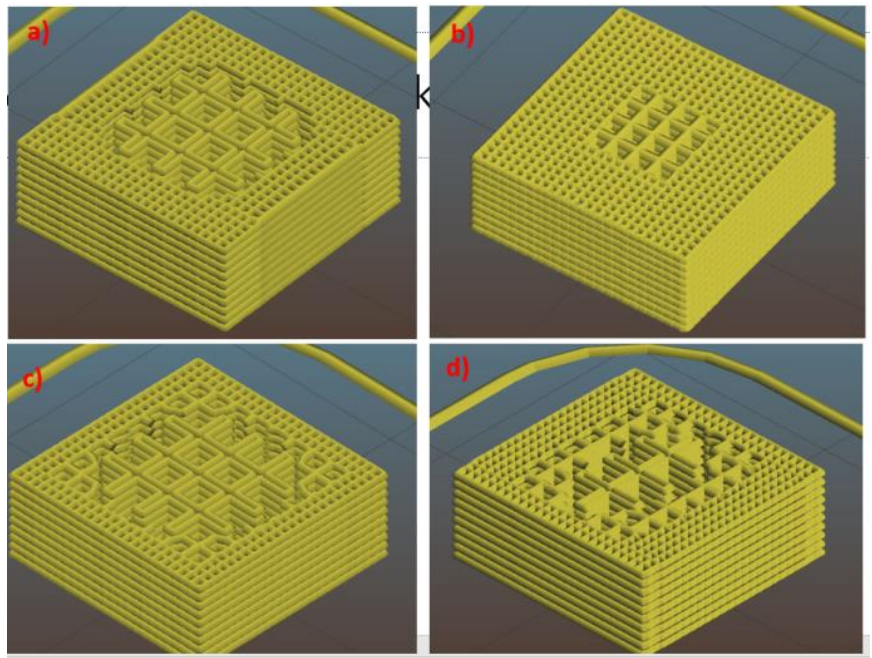

Figure 2. The CAD data of the scaffolds sliced with slic $3 \mathrm{r}$ a) 200-500 $\mu \mathrm{m}-a$, b) 200-500 $\mu \mathrm{m}-b$, c) 200-300-500 $\mu \mathrm{m}-a$, d) 200$300-500 \mu m-b$

\section{Results and Discussion}

Static analysis was performed by using $100 \mathrm{~N}$ load. This test conditions were determined considering the literature and the real working conditions of bones. The result of stress analysis and distribution on the scaffolds can be seen in Figure 3. The maximum Von Misses stress was obtained at 200-300-500 $\mu \mathrm{m}-\mathrm{a}$ scaffold as $2.94 \times 106 \mathrm{~N} / \mathrm{m} 2$. The maximum stress was located on the smaller pores. It can be caused by smaller cross-section than the others can. The maximum deflection is $0.00445 \mathrm{~mm}$ as shown in Figure 4.

Porosity is known as the percentage of void area in a scaffold and is a crucial factor for scaffold design and bone formation. According to FEA results in Table 2, due to its lower porosity 200$500 \mu \mathrm{m}-\mathrm{b}$ hybrid scaffold had highest mechanical properties. Porosity had negative effect on the mechanical properties of the scaffolds.

Table 2. FEA results for the hybrid scaffolds

\begin{tabular}{llll}
\hline Scaffold & $\begin{array}{l}\text { Max } \\
\text { Displacement } \\
(\mathrm{mm})\end{array}$ & $\begin{array}{l}\text { Max. Von } \\
\text { Mises } \\
\text { Stress } \\
\left(\mathrm{N} / \mathrm{m}^{2}\right)\end{array}$ & $\begin{array}{l}\text { Porosity } \\
(\%)\end{array}$ \\
\hline $200-500 \mu \mathrm{m}-\mathrm{a}$ & 0.00373 & $2.71 \times 10^{6}$ & 24.275 \\
$200-500 \mu \mathrm{m}-\mathrm{b}$ & 0.00274 & $1.85 \times 10^{6}$ & 23.05 \\
$200-300-500 \mu \mathrm{m}-\mathrm{a}$ & 0.00445 & $2.94 \times 10^{6}$ & 27 \\
$200-300-500 \mu \mathrm{m}-\mathrm{b}$ & 0.00405 & $2.73 \times 10^{6}$ & 24.85 \\
\hline
\end{tabular}
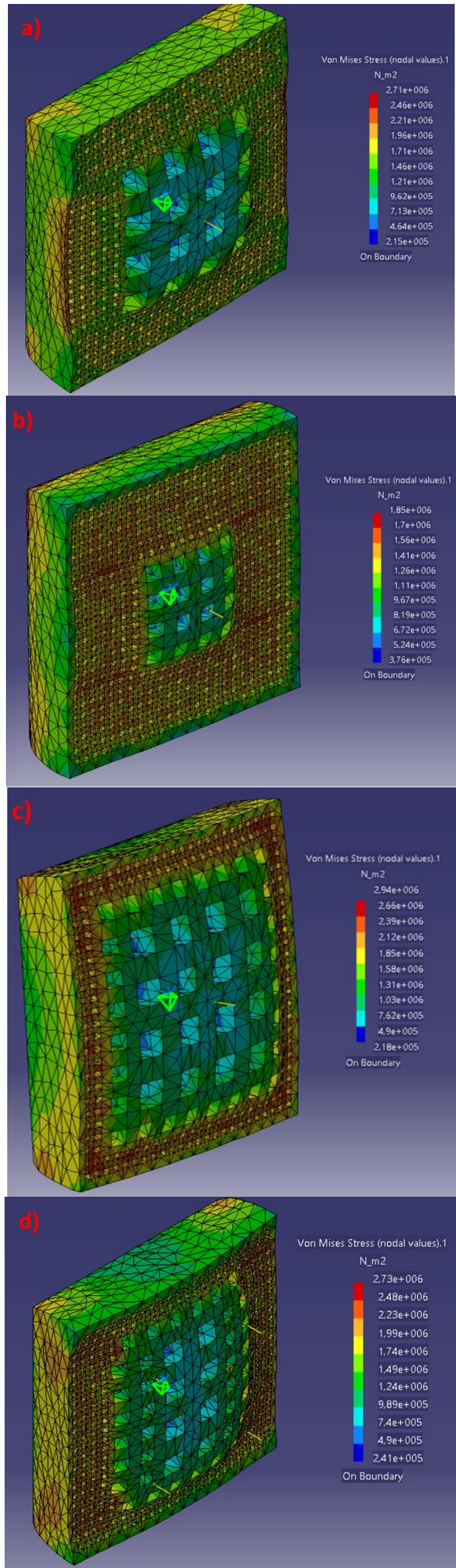

Figure 3. Von Mises Stress distribution under the load of $100 \mathrm{~N}$ a) 200-500 $\mu \mathrm{m}-a$, b) 200-500 $\mu \mathrm{m}-b$, c) 200-300-500 $\mu \mathrm{m}-a$, d) 200-300-500 $\mu \mathrm{m}-b$ 


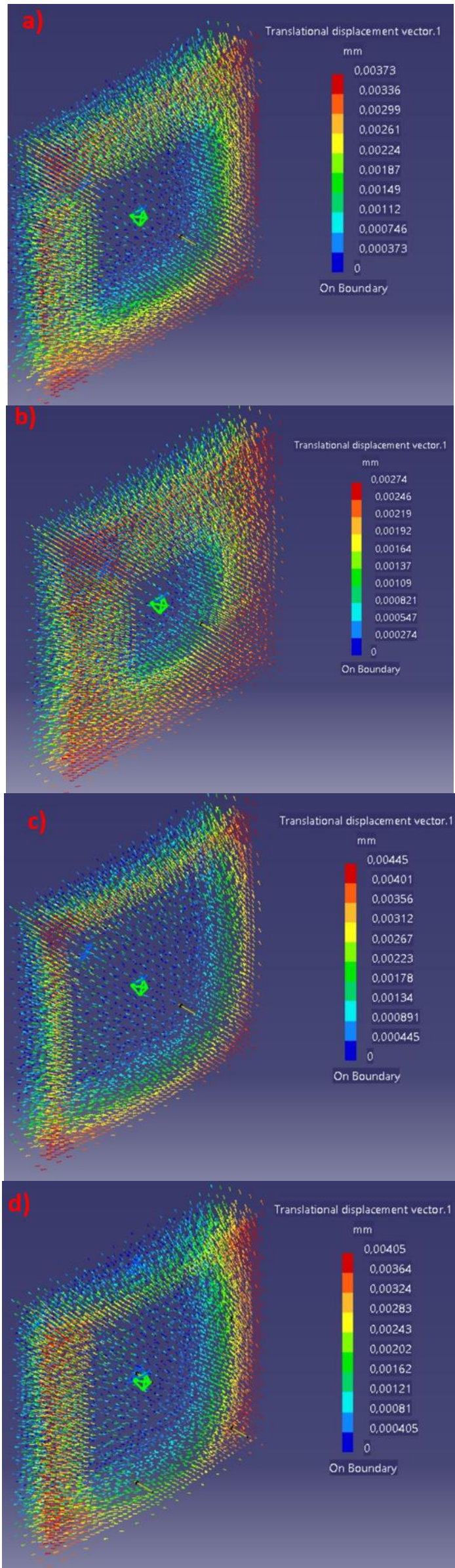

Figure 4 Displacement under the load of $100 \mathrm{~N}$ a) 200-500 $\mu \mathrm{m}$ $a$, b) 200-500 $\mu \mathrm{m}-b$, c) 200-300-500 $\mu \mathrm{m}-a$, d) 200-300-500 $\mu \mathrm{m}-b$

\section{Conclusions}

Stress analysis of the hybrid scaffolds with graded porosity is carried out and maximum stress is identified at the smaller pores. According to FEA results, due to its lower porosity $200-500 \mu \mathrm{m}$ $\mathrm{b}$ hybrid scaffold had highest mechanical properties. Porosity had negative effect on the mechanical properties of the scaffolds.

\section{References}

[1] Barletta, M., Gisario, A., \& Mehrpouya, M. (2021). 4D printing of shape memory polylactic acid (PLA) components: Investigating the role of the operational parameters in fused deposition modelling (FDM). Journal of Manufacturing Processes, 61, 473-480.

[2] Shie, M. Y., Shen, Y. F., Astuti, S. D., Lee, A. K. X., Lin, S. H., Dwijaksara, N. L. B., \& Chen, Y. W. (2019). Review of polymeric materials in $4 \mathrm{D}$ printing biomedical applications. Polymers, 11(11), 1864.

[3] Garg, A., \& Bhattacharya, A. (2017). An insight to the failure of FDM parts under tensile loading: finite element analysis and experimental study. International Journal of Mechanical Sciences, 120, 225-236.

[4] Farbman, D., \& McCoy, C. (2016, June). Materials testing of 3D printed ABS and PLA samples to guide mechanical design. In International Manufacturing Science and Engineering Conference (Vol. 49903, p. V002T01A015). American Society of Mechanical Engineers.

[5] Surmeneva, M. A., Surmenev, R. A., Chudinova, E. A., Koptioug, A., Tkachev, M. S., Gorodzha, S. N., \& Rännar, L. E. (2017). Fabrication of multiple-layered gradient cellular metal scaffold via electron beam melting for segmental bone reconstruction. Materials \& Design, 133, 195-204.

[6] Özeren, E., \& Altan, M. (2020). Effect of structural hybrid design on mechanical and biological properties of $\mathrm{CoCr}$ scaffolds fabricated by selective laser melting. Rapid Prototyping Journal, 26(4), 615-624. 